\title{
Preference for envenomated rodent prey by rattlesnakes
}

\author{
DAVID DUVALL, DAVID CHISZAR, and JEANNE TRUPIANO \\ University of Colorado, Boulder, Colorado 80309 \\ and \\ CHARLES W. RADCLIFFE \\ Denver Zoological Gardens, Denver, Colorado 80205
}

\begin{abstract}
Adult specimens of several rattlesnake species which struck and envenomated a mouse or which did not have an opportunity to strike were allowed to choose between an envenomated mouse and one manually killed by the experimenter. Only rattlesnakes that struck a mouse made a choice, and the envenomated mouse was selected most frequently. Odor cues emanating from the envenomated mouse and/or remembrance of taste or odor cues briefly experienced during the strike probably mediated eventual selection of the envenomated mouse, and may represent important components of the stimulus configuration releasing swallowing once dead prey are located.
\end{abstract}

Rattlesnakes and two species of European viper, Vipera berus and $V$. aspis, follow odor trails laid by envenomated mice that the snakes have struck and then released (Baumann, 1927, 1928, 1929; Dullemeijer, 1961; Naulleau, 1964; Wiedemann, 1932). An envenomated mouse may wander several meters from the snake before dying. Hence, odor trailing (mediated by the vomeronasal system; Dullemeijer, 1961) greatly increases the probability that a snake will locate its dead prey.

Rattlesnakes as well as European vipers are known to be capable of discriminating between experimental odor trails made from envenomated mice and mice killed by other means (Baumann, 1929; Dullemeijer, 1961; see Burghardt, 1970, for a review). The present report asks whether this discriminatory ability will lead snakes to prefer envenomated mice in a paired comparison procedure. Is the tendency to follow an envenomated mouse's trail associated with a tendency to select an envenomated mouse rather than a nearby control mouse? Or do the acts of grasping and swallowing depend on cues (e.g., tactile, visual) different from those utilized in trailing, such that any mouse at the end of the preferred trail will release swallowing?

\section{METHOD}

Twenty-five rattlesnakes (two Crotalus atrox, one $C$. durissus,

Financial support for this project was provided by the M. M. Schmidt Foundation. We thank Kent Scudder for observational assistance, James Barr for helpful criticisms, and Dr. H. P. Alpern, Institute for Behavioral Genetics and Department of Psychology, University of Colorado, Boulder, Colorado, for supplying the inbred mice used in this study. David Duvall's address is now Department of E. P. O. Biology, University of Colorado, Boulder, Colorado 80309. two $C$. enyo, two $C$. lepidus, one $C$. mitchelli, one $C$. pricei, one $C$. triseriatus, seven $C$. viridus, two $C$. willardi, and six Sistrurus catenatus) were each given several opportunities to discriminate between, select, and swallow either a manually killed (cervically dislocated) mouse or one that had been killed by envenomation. In separate sessions, the individually caged snakes were allowed either to strike a mouse (Condition S) or to observe but not strike a mouse (Condition NS) just prior to the choice test. Most snakes were tested four or five times, three or four times in Condition S and once in Condition NS. Since all trials were conducted with an intertrial interval (ITI) of one week, all observations were considered to be independent. In Condition NS each snake was given a choice between a manually killed mouse and a second dead mouse envenomated by another snake of the same species. In Condition $S$ each snake was given a choice between a manually killed mouse and a dead one which it had struck and envenomated. ${ }^{1}$ At the approximate moment of death, the two mice were placed into the snake's cage; the mice were parallel (nearly adjacent) to each other and in the same orientation, equidistant from the predator's head. The maximum duration of an experimental session was $20 \mathrm{~min}$, and records were kept of the total number of tongue flicks emitted, latency to grasp and swallow, and which, if either, of the mice was grasped and swallowed. Tongue flicks were tallied for $20 \mathrm{~min}$ or until a mouse was grasped; in both cases data were expressed as mean number of flicks per minute.

\section{RESULTS}

A total of 118 observations were made, 94 under Condition S and 24 under Condition NS. A strike by the snakes appeared to be crucial to prey selection and swallowing. Of the 94 tests under Condition S, 27 (28.7\%) instances of no selection of either mouse were observed, while $67(71.3 \%)$ selections were made (a selection was scored when a snake grasped one of the mice; swallowing usually, but not always, occurred consequent to grasping). Of the 24 tests under Condition NS, 19 (79.2\%) instances of no selection and only 
$5(20.8 \%)$ instances of selection were observed $\left(\chi^{2}=\right.$ $8.17, \mathrm{df}=1, \mathrm{p}<.005)$.

Focusing only on the selection data from Condition S, 46 cases $(68.7 \%)$ involved selection of envenomated mice, while 21 (31.3\%) involved selection of manually killed mice $\left(\chi^{2}=9.40, \mathrm{df}=1, \mathrm{p}<.005\right)$. In 43 cases the envenomated mouse was swallowed and in 24 cases the manually killed mouse was swallowed $\left(\chi^{2}=5.39, \mathrm{df}=1, \mathrm{p}<.05\right)$. In most tests $(52$, or $77.6 \%)$ snakes contacted both mice (by tongue flicking, and head nudging) before making a selection. Hence, grasping and swallowing appeared to depend upon analysis of chemical cues arising from dead prey. Analysis of variance applied to core (rectal) body temperatures of the two types of dead mice at the approximate moment they were placed into the snakes' cages yielded an insignificant difference (mean for envenomated mice $=$ $36.31^{\circ} \mathrm{C}$, mean for manually killed mice $=36.83 ; \mathrm{F}<1$ ). This suggests that snakes were not using infrared (i.e., heat) reception in making selections and strengthens the previous conclusion that chemical cues were utilized.

Snakes in the two conditions displayed different levels of tongue flicking during the test sessions. In Condition $\mathrm{S}$ the mean number of tongue flicks per minute was 19.0 , while the mean was 4.8 in Condition NS $(\mathrm{F}=32.94, \mathrm{df}=1 / 116, \mathrm{p}<.001)$.

\section{DISCUSSION}

Results indicate that (1) adult rattlesnakes can discriminate dead mice which they have envenomated from others manually killed by the experimenter and that (2) the snakes "prefer" to consume the former, as indexed by both grasping and swallowing. Absence of core body temperature differences of envenomated vs. manually killed mice and discriminability of odor trails made by envenomated mice (Dullemeijer, 1961) suggest that the observed preference effect is mediated by chemical messengers. It is also safe to conclude that cues utilized in odor trailing (i.e., prey location) are also involved in the release of grasping and swallowing.

The rattlesnake's preference for an envenomated mouse may be based upon (1) changes in mouse odor or taste as a function of envenomation, (2) residual saliva or venom from the pitviper's attack remaining on the body surface of the mouse (Wiedemann, 1932), (3) mouse alarm factors (Rottman \& Snowdon, 1972), and/or (4) remembrance by the snakes of odor or taste cues emanating from the envenomated mouse, briefly experienced during the initial attack. Experiments designed to test each of these possibilities are currently in progress.

Elevated tongue-flick rates among rattlesnakes which were allowed to strike prey are consistent with other work completed in this laboratory (Chiszar \& Radcliffe, 1976; Chiszar, Radcliffe, \& Scudder, in press; Scudder, Note 1), indicating that striking "switches-on" chemosensory searching. Our data also suggest that, for the particular group of snakes utilized in the present experiment, swallowing of prey usually will not occur unless a successful strike has been delivered. If this latter effect can be generalized, it suggests that nonstarved and well-acclimated specimens of many rattlesnake species may eat only when they have struck, only what they have struck, and probably little carrion.

\section{REFERENCE NOTE}

1. Scudder, K. M. Perceptual switching in rattlesnakes during feeding episodes. Paper presented at the meeting of the Animal Behavior Society, Boulder, Colorado, June 1976.

\section{REFERENCES}

Baumann, F. Experimente uber den Geruchssinn der viper. Revue Suisse de Zoologie, 1927, 34, 173-184.

Bauman, F. Uber die bedeutung des bisses und des geruchssinnes fur den nahrungserwerb der viper. Revue Suisse de Zoologie, 1928, 35, 233-239.

Baumann, F. Experimente uber den geruchssinn und der beuterwerb der viper [Viper aspis L.]. Zeitschrift fur Vergleichende Physiologie, 1929, 10, 36-119.

Burghardr, G. M. Chemical perception in reptiles. In J. W. Johnston, D. G., Moulton, \& A. Turk (Eds.), Communication by chemical signals. New York: Appleton-Century-Crofts, 1970.

Chiszar. D. \& Radcliffe, C. W. Rate of tongue flicking by rattlesnakes during successive stages of feeding on rodent prey. Bulletin of the Psychonomic Society, 1976, 7. 485-486.

Chiszar. D., Radcliffe, C. W., \& Scudder, K. M. Analysis of the behavioral sequence emitted by rattlesnakes during feeding episodes: I. Striking and chemosensory searching. Behavioral Biology, in press.

Dullemeijer, P. Some remarks on the feeding behavior of rattlesnakes. Koninklijke Nederlandische Academie van Wetenschappen. Series C. 1961, 64, 383-396.

Naulleau, G. Premieres observations sur le comportement de chasse et de capture chez les viperes et les couleuvres. La Terre et la Vie. 1964, 1, 54-76.

Rotrman. S. J.. \& Snowdon, C. T. Demonstration and analysis of an alarm pheromone in mice. Journal of Comparative and Physiological Psychology, 1972, 81, 483-490.

Wiedemans, E. Zur biologie der nahrungs-aufnahme der kreuzotter [Viper berus L.]. Zoologischer Anzeiger, 1932, 97. 278-286.

\section{NOTE}

1. Envenomation was accomplished by dangling a mouse (suspended from long forceps) into the snake's cage. Each snake usually struck immediately, and the mouse was removed immediately after it was struck. This mouse was placed back into the cage (along with a fresh manually killed control) as soon as it died (usually within $3 \mathrm{~min}$ ). The envenomated mouse was not allowed to run about the cage, thus filling the floor with its odors. Hence, the subsequent choice test did not confound odors present during the test with odors deposited prior to the test.

(Received for publication September 12, 1977.) 